Artikel Penelitian

\title{
Preparasi dan Karakterisasi Nanobiokatalis Mikroreaktor dengan Polimer Monolitik Nanopori Enzim Termobilisasi
}

\author{
Baiq Octaviana D. Anggraeny ${ }^{1}$, Septi F. Raeni ${ }^{1}$, Elvina D. Iftitah ${ }^{1,2}$, Akhmad Sabarudin ${ }^{1}, 2^{*}$ \\ 1 Jurusan Kimia, Fakultas Matematika dan IImu Pengetahuan Alam, Universitas Brawijaya, Malang, Indonesia \\ ${ }^{2}$ Kelompok Penelitian Advanced System and Material Technology, Universitas Brawijaya, Malang, Indonesia
}

\section{INFO ARTIKEL}

Sejarah artikel:

Revisi 27 Februari 2017

Diterima 20 Maret 2017

Tersedia online 03 Mei 2017

*Penulis korespondensi

Email: sabaripn@ub.ac.id

\section{ABSTRAK}

Nanobiocatalyst microreactor column of an immobilized trypsin onto nanoporous monolithic polymer has been developed. In this work, a poly (glycidyl methacrylate-co-ethylene glycol dimethacrylate) (poly(GMA-coEDMA)) monolih with total monomer \%T 40 and cross-linker \%C 25 was prepared as a nanoporous polymeric-support by in-situ copolymerization inside the microbore silicosteel tubing $(1.0 \mathrm{~mm}$ i.d $\times 100 \mathrm{~mm})$. This nanoporous monolithic-support was chemically modified with trypsin through the ring-opening reaction of epoxide group to form a nanobiocatalyst microreactor. In order to obtain reliable microreactor, some parameters such as immobilization time (amount of trypsin), and effect of glutaraldehyde activation on the trypsin-immobilized monolithic column were optimized. The pore size distribution, morphology and elemental composition of the monolith were studied by inverse size exclusion chromatography (ISEC) and scanning electron microscopy (SEM-EDX), respectively. While permeability of the monolith was obtained through measurement of its back pressure using HPLC pump. The monolith was predominated by mesoporous content $(65.85 \%)$ while the flow-through pore was $28.20 \%$. From SEM-EDX, it was found that the highest nitrogen content (12.40\%), which indicates the amount of trypsin chemically attached on the monolitic support, was found in the nanobiocatalyst microreactor with immobilization time $4 \mathrm{~h}$ without glutaraldehyde as activation agent. The optimized nanobiocatalyst microreactor column was successfully applied to a rapid and efficient digestion of protein samples in the range of second to minute.

Keywords: nanoporous monolit, immobilized enzyme, nanobiocatalyst microreactor, protein digestion

Pada penelitian ini telah dilakukan pengembangan pembuatan kolom nanobiokatalis mikroreaktor yang terimobilisasi oleh enzim tripsin pada polimer monolitik nanopori. Polimer monolitik nanopori dibuat secara insitu kopolimerisasi dalam kolom silicosteel $(1.0 \mathrm{~mm}$ i.d x $100 \mathrm{~mm})$ dari monomer GMA dan EDMA sebagai crosslinker serta penambahan porogen dengan komposisi 1-propanol/1,4-butanediol/air (7:4:1) dan inisiator radikal AIBN 1\%. Proses polimerisasi berlangsung selama 12 jam pada suhu $60^{\circ} \mathrm{C}$ dengan persentase total monomer $\% \mathrm{~T} 40$ dan persentase crosslinker \%C 25. Monolit dimodifikasi secara kimia menggunakan metode imobilisasi enzim melalui reaksi pembukaan cincin 
epoksida dari polimer monolit terhadap tripsin. Beberapa parameter uji dilakukan untuk menghasilkan mikroreaktor pada kondisi optimum yaitu variasi waktu imobilisasi dan pengaruh penambahan glutaraldehida pada kolom tripsin monolit. Karakterisasi yang dilakukan meliputi uji ISEC untuk mengetahui ukuran dan distribusi pori monolit, SEM-EDX untuk mengetahui struktur morfologi kolom mikroreaktor, dan uji permeabilitas kolom mikroreaktor. Berdasarkan hasil ISEC proporsi mesopori dan makropori (flow-through pore) seimbang yaitu $65,85 \%$ dan $28,20 \%$. Hasil SEM-EDX menunjukkan kandungan nitrogen tertinggi yang mewakili jumlah tripsin yang terimobilisasi dalam monolit sebesar 12,40\% dihasilkan dari tripsin monolit dengan waktu imobilisasi 4 jam tanpa penambahan glutaraldehida. Nanobiokatalis mikroreaktor pada kondisi optimum dapat digunakan untuk proses digestion sampel protein secara cepat dan efisien.

Kata kunci: monolit nanopori, imobilisasi enzim, nanobiokatalis mikroreaktor, protein digestion

\section{Pendahuluan}

Di bidang proteomik, mikroreaktor merupakan alat yang digunakan untuk pemetaan peptida. Pada proses ini protein diidentifikasi melalui identifikasi fragmen peptida yang dihasilkan setelah mengalami proteolisis (Stigter, de Jong \& van Bennekom, 2007). Pembuatan mikroreaktor masih perlu dikembangkan berkaitan dengan peningkatan kinerja mikroreaktor tersebut yaitu dengan adanya material pendukung (solid support material). Beberapa jenis material pendukung yang dapat digunakan adalah membran, fiber, microchip, nanopartikel, silika, dan monolit. Beberapa peneliti telah mengembangkan material pendukung berbasis monolit yang disebut monolitik mikroreaktor. Penelitian yang telah dilakukan oleh Tasfiyati, Iftitah, Sakti \& Sabaruddin (2016), membuat monolit mikroreaktor dari poli(GMA-coEDMA) melalui modifikasi gugus aktif menggunakan dietilamin diaplikasikan sebagai kolom penukar anion lemah untuk pemisahan sampel DNA termetilasi.

Mikroreaktor nanobiokatalis merupakan mikroreaktor yang modifikasi gugus aktif material pendukungnya dilakukan dengan menambahkan senyawa biomolekul seperti enzim. Mikroreaktor nanobiokatalis dapat dibuat melalui beberapa metode yang diperlukan untuk meningkatkan kinerjanya. Salah satu metodenya yaitu imobilisasi enzim (Kim, Kim, Lopez-Ferrer, Petritis, \& Smith, 2010). Metode ini dapat berlangsung secara adsorpsi, entrapment, ikatan kovalen (covalent bonding) dan pengikat-silang (crosslinking) (Safdar, Sprob, \& Janis, 2014). Penggabungan antara kedua jenis pendekatan yaitu ikatan kovalen dan pengikat-silang disebut dengan pelapisan enzim (enzyme coating). Pendekatan secara pelapisan enzim diharapkan mampu meningkatkan jumlah enzim dari satu lapisan (monolayer) menjadi beberapa lapisan (multilayer). Keunggulan penggunaan metode ini dapat meningkatkan stabilitas enzim, meningkatkan volume spesifik enzim yang terikat pada material pendukung (enzyme loading), dan bersifat reusable atau dapat digunakan kembali (Chen et al., 2011; Shangguan et al., 2015). Imobilisasi enzim pada suatu mikroreaktor juga memiliki efisiensi pemecahan (digestion) tinggi dan dapat dengan mudah dihubungkan dengan sistem pemisahan dan deteksi secara otomatis (Liang et al., 2011).

Protein digestion merupakan suatu proses pemecahan protein menjadi peptida-peptidanya. Proses pemecahan disebut dengan analisis proteomik. Studi mengenai proteomik berfokus pada karakterisasi biomolekul yang berbeda. Selain itu, studi ini juga berkaitan dengan proses identifikasi keseluruhan protein dalam sel, dan jaringan (Liang et al., 2011). Pada awal pengembangannya, studi mengenai protein digestion dilakukan menggunakan metode konvensional (offline). Pemisahan berlangsung di dalam suatu larutan campuran protein (batch wise method) yang diinkubasi dalam waktu 24 jam. Pada dasarnya, metode pemisahan dalam larutan masih belum efisien terutama dalam aplikasinya untuk penggunaan rutin. Seiring dengan berkembangnya ilmu pengetahuan metode tersebut mulai ditinggalkan karena dinilai memiliki 
kelemahan yaitu waktu digestion lama, autodigestion pada enzim tidak dapat dihindari, reproduksibilitas rendah dan berlangsung secara offline sehingga distribusi enzim dalam larutan tidak merata (Liang et al., 2011; Safdar et al., 2014). Hal tersebut sangat berbanding terbalik dengan metode online digestion, dimana pada metode tersebut semua prosesnya berlangsung secara online menggunakan sistem HPLC dalam sebuah kolom mikroreaktor sehingga efisiensi waktu pemisahan meningkat karena hanya berlangsung dalam hitungan menit.

Dalam penelitian ini akan dilakukan pembuatan mikroreaktor nanobiokatalis dengan menggunakan polimer monolitik nanopori (poly-(GMA-co-EDMA)) dalam kolom silicosteel secara in-situ kopolimerisasi antara monomer glycidyl methacrylate (GMA) dan ethylene glycol dimethacrylate (EDMA). Inisiator radikal (AIBN) digunakan dalam proses tersebut dengan adanya porogen 1-propanol/1,4-butanadiol/air. Selanjutnya, tripsin diimobilisasi ke dalam monolit. Proses tersebut akan menghasilkan mikroreaktor nanobiokatalis yang dalam penelitian ini disebut dengan trypsin immobilized monolit microreactor (TIMM). Sebagai pembanding, dilakukan pula pembuatan mikroreaktor nanobiokatalis yang sama dan diaktivasi dengan penambahan glutaraldehida sebagai agen pengikat-silang sehingga disebut sebagai trypsin immobilized monolit microreactorglutaraldehyde (TIMM-G).

\section{Bahan dan metode}

\subsection{Bahan}

Bahan yang digunakan adalah glisidil metakrilat (GMA) $97 \%$, etilen dimetakrilat (EDMA) 98\%, 3-(Trimetoksisilil)propil metakrilat (MAPS) 98\%, 1-propanol, 1,4-butanadiol 99\%, a,a'azoisobutironitril (AIBN), tripsin, glutaraldehida $25 \%$, dan benzamidin hidroklorida $>96 \%$. Bahan lain yang digunakan yaitu natrium hidrogen karbonat $>99 \%$, natrium karbonat, amonium bikarbonat $>99 \%$, $\beta$-kasein, sitokrom C, asetonitril (ACN), etanol, piridin, $\mathrm{NaOH}, \mathrm{HCl}$ dan asam trifloroasetat (TFA). Adapun kolom yang digunakan adalah kolom silicosteel (panjang $10 \mathrm{~cm}$, diameter luar $1 / 16$ inci dan diameter dalam 1,0 mm).

\subsection{Pembuatan TIMM dan TIMM-G}

Tahap pertama dilakukan pembuatan monolit poli(GMA-co-EDMA) dengan \%T 40 dan \%C 25
(Tasfiyati et al., 2016). Modifikasi monolit dilakukan dengan mengalirkan $10 \mathrm{mg} / \mathrm{mL}$ tripsin ditambahkan $0,005 \mathrm{M}$ benzamidin hidroklorida dalam 0,1 M bufer karbonat $(\mathrm{pH} 10,5)$ pada monolit tersebut. Variasi waktu imobilisasi dilakukan selama 2, 4 dan 6 jam. Tahap kedua, tripsin-monolit (nanobiokatalis mikroreaktor) dicuci dengan mengalirkan $1 \mathrm{M} \mathrm{NaCl}$ dalam 0,1 M bufer karbonat (pH 10,5). Tahap selanjutnya, dicuci kembali dengan mengalirkan benzamidin hidroklorida dalam 0,1 M bufer karbonat $(\mathrm{pH} 10,5)$. Kedua tahapan pencucian tersebut dilakukan selama 20 menit dengan laju alir $0,05 \mathrm{~mL} / \mathrm{menit}$ pada suhu ruang dan dilakukan penyimpanan pada suhu $4^{\circ} \mathrm{C}$ sebelum digunakan.

Pembuatan TIMM-G dilakukan dengan mengalirkan gluteraldehida $5 \%$ dalam $0,1 \mathrm{M}$ ammonium bikarbonat $(\mathrm{pH}$ 8) pada suhu ruang selama 2 jam. Kemudian, nanobiokatalis mikrorekator dicuci dengan mengalirkan etanol selama 1 jam dengan laju alir $0,05 \mathrm{~mL} /$ menit pada suhu ruang dan dilakukan penyimpanan pada $4^{\circ} \mathrm{C}$ sebelum digunakan.

\subsection{Uji distribusi pori menggunakan metode ISEC}

Penentuan distribusi pori monolit poli(GMA-coEDMA) dilakukan dengan metode ISEC menggunakan senyawa toluen dan polistiren standar dengan berat molekul $5 \times 10^{2}-2 \times 10^{6} \mathrm{~g} / \mathrm{mol}$. Fasa gerak yang digunakan adalah THF dengan panjang gelombang deteksi $254 \mathrm{~nm}$. Masingmasing standar diinjeksi dengan volum $2 \mu \mathrm{L}$, laju alir $0,05 \mathrm{~mL} / \mathrm{menit}$ pada suhu ruang. Analisis proporsi flow-through pores, mesopores, dan micropores dihitung berdasarkan metode pada Persamaan 1 (Al-Bokari, Cherrak, \& Guiochon, 2002).

$M_{w}=2,25 \varnothing_{n} 1,7$

Dimana $M_{w}$ adalah berat molekul, $\varnothing$ adalah diameter pori (Angstrom), dan $\mathrm{n}$ adalah bilangan bulat yang menyatakan urutan ukuran pori $\left(\varnothing_{n+1}>\right.$ $\left.\emptyset_{n}\right)$

Volume yang berkorelasi dengan diameter pori dihitung berdasarkan selisih dari volume retensi 2 berat molekul yang berurutan, sesuai dengan Persamaan 2.

$\Delta V_{n+1, n}=V_{R n+1}-V_{R n}$

$V_{n}$ menyatakan fraksi volume dari pori yang mempunyai ukuran setara atau lebih besar dari $\emptyset_{n}$. Distribusi pori dinyatakan dalam grafik hubungan antara fraksi volume dan logaritma diameter pori. 


\subsection{Uji permeabilitas}

Permeabilitas monolit diketahui berdasarkan data tekanan balik yang terukur ketika fasa gerak dialirkan dan dihitung menggunakan Persamaan 3 yaitu persamaan Darcy dengan konversi satuan 1 Darcy $=9,9 \times 10^{-13} \mathrm{~m}^{2}$.

$K=\frac{\eta \cdot L \cdot u}{\Delta p}=\frac{\eta \cdot L \cdot F_{m}}{\Delta p \cdot \pi \cdot r^{2}}$

$\mathrm{K}=$ Permeabilitas $\left(\mathrm{m}^{2}\right)$

$\eta \quad=$ Viskositas fasa gerak (Pa.s)

$\mathrm{L} \quad=$ Panjang kolom $(\mathrm{cm})$

$\Delta \mathrm{P}=$ Tekanan balik $(\mathrm{Pa})$

$\mathrm{u} \quad=$ Laju linier fasa gerak $(\mathrm{m} / \mathrm{s})$

$F_{m}=$ Laju alir fasa gerak $\left(\mathrm{m}^{3} / \mathrm{s}\right)$

$r \quad=$ Jari-jari $\operatorname{kolom}(\mathrm{m})$

\subsection{Scanning electron microscopy (SEM-EDX)}

Karakterisasi morfologi TIMM dan TIMM-G dilakukan dengan SEM yang dilengkapi dengan EDX (Energy Dispersive X-Ray Analysis).

\section{Hasil dan pembahasan}

\subsection{Pembuatan TIMM dan TIMM-G}

Pada penelitian ini monolit poly-(GMA-coEDMA) dibuat dalam kolom silicosteel tersilanasi. Proses silanasi dalam kolom silicosteel dilakukan dengan cara menghidrolisis kolom menggunakan larutan yang bersifat asam $(\mathrm{HCl})$ dan basa $(\mathrm{NaOH})$. Penambahan MAPS bertujuan untuk memudahkan terbentuknya ikatan kovalen antara permukaan dinding bagian dalam dari kolom silicosteel dengan polimer. Reaksi silanasi pada permukaan dinding dalam kolom silicosteel yang berlangsung antara gugus silanol dengan gugus metoksi dari senyawa MAPS ditunjukkan pada Gambar 1 (Bystrom, 2009).

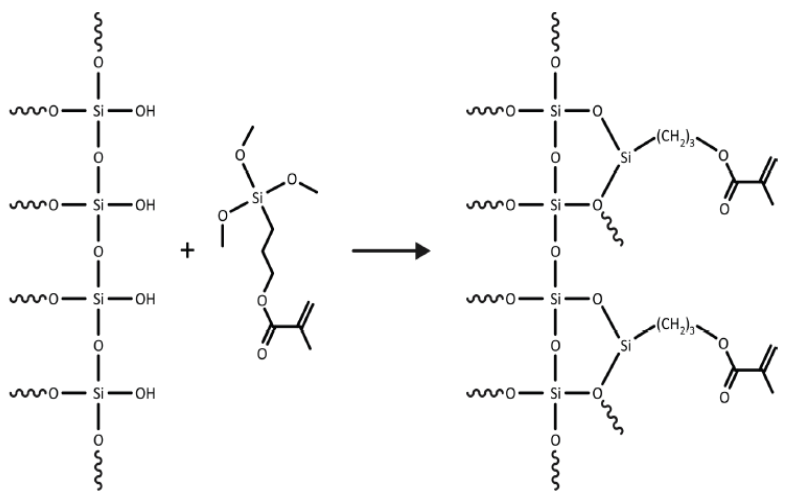

Gambar 1. Reaksi silanasi kolom silicosteel menggunakan MAPS
Monolit polimer dibuat secara in situ polimerisasi dalam kolom silicosteel melalui campuran monomer GMA, agen ikat silang EDMA, campuran porogen (1-propanol, 1,4-butanadiol, dan air), dan inisiator radikal AIBN. Dalam penelitian ini, rasio $\% \mathrm{~T}$ dan $\% \mathrm{C}$ yang digunakan yaitu $40 \%$ dan $25 \%$.

Pemilihan komposisi monomer dan agen pengikat-silang didasarkan pada penelitian yang telah dilakukan oleh Tasfiyati et al. (2016) menggunakan kondisi optimum poli(GMA-coEDMA) yang diperoleh pada komposisi tersebut. Polimerisasi berlangsung secara adisi polimerisasi (chain growth reaction) antara dua monomer yang berbeda membentuk rangkaian kopolimer yang acak. Penggunaan inisiator dalam proses kopolimerisasi sangat mempengaruhi porositas monolit. Inisiator AIBN akan membentuk radikal pada suhu $40-80^{\circ} \mathrm{C}$. Pada penelitian ini polimerisasi berlangsung selama 12 jam dengan suhu polimerisasi $60^{\circ} \mathrm{C}$.

Modifikasi terhadap monolit poli(GMA-coEDMA) dilakukan dengan melalui reaksi imobilisasi dengan enzim tripsin yang ditambahkan dengan benzamidin hidroklorida. Senyawa tersebut digunakan untuk mengkondisikan tripsin agar tidak mengalami denaturasi dalam kondisi bebas (suhu ruang). Dalam penelitian ini, dilakukan 3 variasi waktu imobilisasi tripsin terhadap monolit yaitu 2, 4, dan 6 jam. Variasi waktu imobilisasi dilakukan untuk mengetahui kolom tripsin monolit yang paling optimum berdasarkan pendekatan terhadap banyaknya tripsin yang terikat pada monolit. Selama reaksi imobilisasi berlangsung laju alir yang digunakan adalah $0,05 \mathrm{~mL} /$ menit dengan konsentrasi tripsin $1000 \mathrm{ppm}$. Pencucian kolom menggunakan larutan $\mathrm{NaCl}$ dalam bufer karbonat untuk menghilangkan sisa tripsin yang tidak terikat, dan dibilas menggunakan larutan benzamidin hidroklorida dalam bufer karbonat untuk memblok residu epoksida (Monzo, Rejtar, \& Guttman, 2009). Reaksi imobilisasi tripsin terjadi melalui pembukaan cincin epoksida dari monomer GMA.

Modifikasi lain dilakukan dengan penambahan glutaraldehida $5 \%$ dengan cara mengalirkannya pada laju alir $0,05 \mathrm{~mL} /$ menit selama 2 jam. Penambahan glutaraldehida akan mempengaruhi pembentukan lapisan dari monolayer menjadi multilayer dari tripsin yang terikat secara kovalen dengan gugus epoksida pada permukaan monolit. Gambar 2 menunjukkan ilustrasi keseluruhan reaksi selama proses polimerisasi berlangsung 
hingga proses aktivasi dengan glutaraldehida. Pencucian dilakukan dengan mengalirkan etanol untuk menghilangkan residu glutaraldehida yang tidak terikat. diperoleh 0,24 dan porositas internal $\left(\mathrm{e}_{\mathrm{i}}\right)$ diperoleh 0,41 . Berdasarkan hasil tersebut, monolit memiliki porositas internal yang lebih besar dibandingkan dengan porositas eksternal sehingga karakter mesopori lebih dominan dimiliki oleh fasa diam.

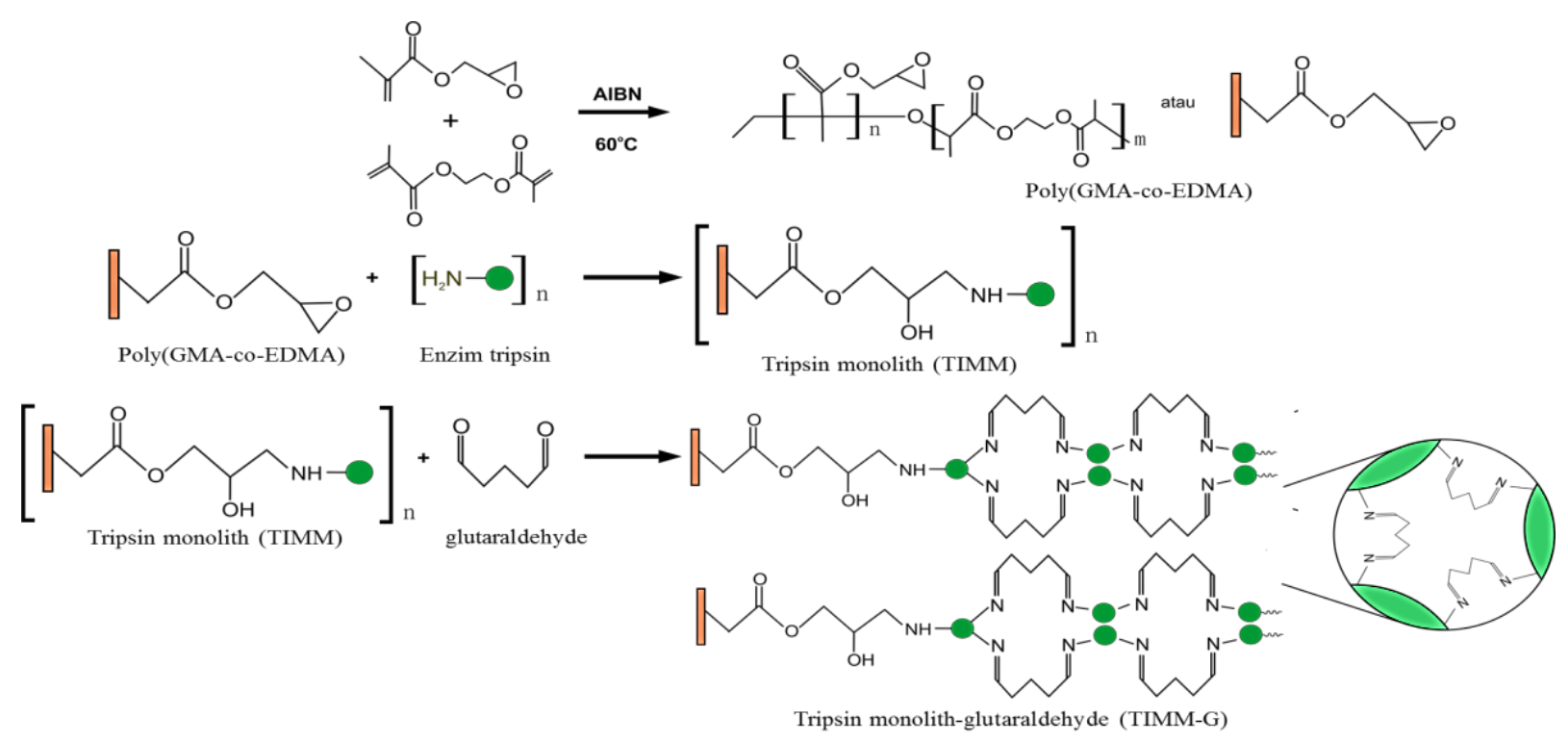

Gambar 2. llustrasi reaksi pembuatan TIMM dan TIMM-G

\subsection{Pengukuran distribusi pori dengan ISEC (Inverse Size Exlusion Chromatography)}

Pengukuran distribusi ukuran pori pada fasa diam (kolom monolit) menggunakan beberapa seri polimer standar atau probe molecules dengan ukuran hidrodinamik molekular yang berbeda. Beberapa seri polimer standar tersebut diinjeksikan secara cepat ke dalam larutan pengelusi. Perbedaan waktu elusi akan tercatat dan dapat dihitung sebagai fungsi ukuran pori dan volume pori (Berthold and Salmen, 1997).

Seri polimer yang digunakan dalam penelitian ini adalah satu set polistiren standar dan toluen. Pengujian dengan ISEC dilakukan dengan menginjeksikan seri polimer tersebut secara terpisah dalam kolom dengan menggunakan fasa gerak THF pada laju alir $0,05 \mathrm{~mL} /$ menit. Toluen sebagai molekul terkecil yang mampu menembus keseluruhan pori monolit akan memberikan waktu retensi yang paling lama. Waktu retensi akan semakin kecil seiring dengan semakin besarnya berat molekul polistiren standar yang diinjeksikan. Adapun volume retensi toluen diasumsikan sebagai volume pori total kolom monolit. Total porositas monolit $\left(e_{t}\right)$ diperoleh 0,65 . Nilai tersebut sesuai dengan fraksi porogen (pore forming agent) monolit poli(GMA-co-EDMA) yang telah dihasilkan sebelumnya yaitu 0,6 . Porositas eksternal
Tabel 1.

Data distribusi ukuran pori kolom monolit poli(GMA-co-EDMA)

\begin{tabular}{lc}
\hline \multicolumn{1}{c}{ Tipe Pori } & Pori (\%) \\
\hline Mikropori $(<2 \mathrm{~nm})$ & 5,950 \\
Mesopori $(2-50 \mathrm{~nm})$ & 65,85 \\
Makropori $(>50 \mathrm{~nm})$ & 28,20 \\
\hline
\end{tabular}

Berdasarkan Tabel 1, hampir $66 \%$ pori yang terbentuk pada monolit merupakan tipe mesopori. Hal ini menunjukkan bahwa luas permukaan monolit yang besar sehingga interaksi antara fasa diam dengan analit berlangsung baik. Monolit yang didominasi oleh tipe mesopori akan mampu memisahkan molekul dengan ukuran besar seperti senyawa-senyawa biomolekul. Dalam penelitian ini, tipe mesopori sangat diharapkan karena berfungsi untuk mengikat aktif molekul (enzim tripsin) dalam jumlah yang lebih banyak. Tipe makropori (flow through pores) yang berfungsi untuk terjadinya transfer massa secara konvektif memiliki proporsi sebesar $28,20 \%$. Tipe makropori ini hanya dapat memisahkan molekul kecil dengan jumlah yang memadai sedangkan tipe mikropori yang terbentuk sebanyak 5,950\%. Proporsi ini diharapkan keberadaannya dengan persentase yang sangat kecil untuk menekan terjadinya pelebaran puncak 
yang disebabkan oleh adanya absorpsi irreversible sehingga mengurangi efisiensi pemisahan.

\subsection{Permeabilitas kolom}

Permeabilitas kolom didefinisikan sebagai tingkat kemampuan kolom dalam meloloskan sejumlah partikel (aliran fasa gerak) yang menenembus atau melaluinya. Fasa gerak yang digunakan dalam pengukuran permeabilitas kolom monolit yaitu etanol. Fasa gerak tersebut akan memberikan nilai tekanan balik yang berbanding terbalik dengan permeabilitas ketika dialirkan melewati kolom. Permeabilitas akan meningkat seiring dengan penambahan tingkat porositas polimer monolit, dan tekanan balik yang dihasilkan rendah. Hal tersebut menunjukkan tingkat kemudahan fasa gerak dalam melewati kolom monolit.

Permeabilitas kolom tripsin monolit poly-(GMAco-EDMA) diuji pada laju alir 0,01-0,1 $\mathrm{mL} /$ menit hingga diperoleh nilai peningkatan tekanan balik yang konstan. Data nilai tekanan balik tersebut dipilih pada laju alir $0,05 \mathrm{~mL} / \mathrm{menit}$ disajikan pada Tabel 2. Secara keseluruhan kolom tripsin monolit memberikan nilai tekanan balik rendah yang menunjukkan bahwa permeabilitas kolom yang tinggi.

Kolom mikroreaktor yang diujikan menggunakan laju alir 0,01-0,1 mL/menit menunjukkan kenaikan tekanan balik secara linier dengan nilai koefisien korelasi mendekati 1 . Nilai tersebut menunjukkan tingkat kestabilan mekanis kolom mikroreaktor yang tinggi. Meskipun terjadi perubahan laju alir dari rendah ke tinggi, TIMM dan TIMM-G tidak mengalami kompresi yang diikuti dengan peningkatan tekanan balik.

Tabel 2.

Permeabilitas kolom TIMM dan TIMM-G

\begin{tabular}{lccc}
\hline $\begin{array}{c}\text { Kolom } \\
\text { Mikro- } \\
\text { reaktor }\end{array}$ & $\begin{array}{c}\text { Waktu } \\
\text { Imobilisasi } \\
\text { (jam) }\end{array}$ & $\begin{array}{c}\text { Tekanan } \\
\text { Balik } \\
\text { (MPa) }\end{array}$ & $\begin{array}{c}\text { Permeabilitas } \\
\text { (darcy) }\end{array}$ \\
\hline \multirow{2}{*}{ TIMM } & 2 & 0,5 & 0,235 \\
& 4 & 0,7 & 0,168 \\
& 6 & 0,6 & 0,196 \\
\hline & 2 & 1,4 & 0,084 \\
TIMM-G & 4 & 0,8 & 0,147 \\
& 6 & 0,8 & 0,147 \\
\hline
\end{tabular}

Berdasarkan Tabel 2 dapat diketahui bahwa dengan membandingkan antara TIMM dengan TIMM-G pada variasi waktu imobilisasi 2, 4, dan 6 jam menunjukkan terjadinya penurunan permeabilitas kolom. Penurunan permeabilitas akibat penambahan glutaraldehida terjadi karena pengaruh perubahan struktur kerapatan pada monolit. Pori pada monolit semakin sedikit karena tertutupi oleh molekul glutaraldehida sehingga semakin rapat monolit yang dihasilkan dan porositas monolit menurun.

\subsection{Scanning electron microscopy (SEM-EDX)}

Morfologi permukaan dan perkiraan ukuran globul polimer monolit poli(GMA-co-EDMA), TIMM dan TIMM-G diamati menggunakan SEM. Berdasarkan hasil pengamatan dengan SEM terlihat bahwa tidak keseluruhan dari morfologi permukaan monolit membentuk globul dengan pori yang saling berhubungan (flow-through pore) (Gambar 3). Hal ini terjadi pada polimer TIMM-G dikeseluruhan variasi waktu imobilisasi sedangkan pada monolit poli(GMA-co-EDMA) dan polimer TIMM keseluruhan permukaan membentuk globul dengan adanya pembentukan pori yang terhubung secara kontinyu.

Struktur morfologi poli(GMA-co-EDMA) \% T 40 dan \%C 25 pada Gambar 3 menunjukkan adanya globul-globul berukuran lebih kecil jika dibandingkan dengan monolit yang telah dimodifikasi. Hal ini terjadi karena pengaruh modifikasi struktur pada monolit yaitu penambahan enzim tripsin. Secara garis besar, morfologi permukaan dari TIMM-G lebih rigid dibandingkan dengan permukaan TIMM.

\section{Tabel 3.}

Data EDX poly-(GMA-co-EDMA), TIMM, dan TIMM-G

\begin{tabular}{lcccc}
\hline \multirow{2}{*}{$\begin{array}{l}\text { Kolom } \\
\text { Mikro- } \\
\text { reaktor }\end{array}$} & $\begin{array}{c}\text { Waktu } \\
\text { Imobilisasi }\end{array}$ & \multicolumn{3}{c}{$\begin{array}{c}\text { Persen Komposisi Unsur } \\
\text { (Wt\%) }\end{array}$} \\
\cline { 3 - 5 } & & $\mathrm{C}$ & $\mathrm{O}$ & $\mathrm{N}$ \\
\hline \multirow{2}{*}{ TIMM } & 2 & 38,17 & 55,29 & 6,540 \\
& 4 & 50,80 & 36,80 & 12,40 \\
& 6 & 47,10 & 42,11 & 10,79 \\
\hline \multirow{2}{*}{ TIMM-G } & 2 & 53,79 & 38,57 & 7,640 \\
& 4 & 50,28 & 24,49 & 25,23 \\
& 6 & 48,21 & 32,92 & 18,87 \\
\hline Poli-(GMA-co-EDMA) & 62,67 & 37,33 & - \\
\hline
\end{tabular}

Rigidnya struktur TIMM-G disebabkan oleh pengaruh penambahan glutaraldehida $5 \%$ dimana molekulnya menutupi keseluruhan pori yang terbentuk diantara globul-globul pada TIMM. Hal ini sesuai dengan data hasil uji permeabilitas kolom 
(Tabel 2). Penambahan glutaraldehida dalam suatu material pendukung yang telah diimobilisasi menggunakan enzim disebut pelapisan enzim (enzyme coating). Teknik ini akan menghasilkan lapisan multilayer dan mencegah terjadinya ketidakstabilan pada enzim (Kim et al., 2011). Hal tersebut terjadi karena jumlah $\mathrm{N}$ yang mewakili enzim tripsin pada TIMM-G mengalami peningkatan dibandingkan dengan TIMM secara keseluruhan (Tabel 3). Namun, hasil pengamatan SEM menunjukkan bahwa penambahan glutaraldehida pada teknik enzyme coating mengakibatkan tertutupnya keseluruhan flowthrough pore yang terbentuk diantara globul-globul sehingga terjadi peningkatan kerapatan monolit.
TIMM terlarut dalam glutaraldehida mengakibatkan terbentuknya permukaan yang lebih rata. Cracking inilah yang menyebabkan permeabilitas kolom ini cukup tinggi karena dimungkinkan fasa geraknya masih bisa melewati bagian monolit yang mengalami cracking. Selain itu, distribusi glutaraldehida pada kolom tidak merata sehingga masih ada globul dan flow-through pore yang tidak tertutupi.

Perbandingan profil SEM pada kondisi penambahan komposisi glutaraldehida yang sama tetapi dengan waktu imobilisasi enzim yang berbeda. Gambar $3(\mathrm{~g}-\mathrm{l})$ menunjukkan bahwa lama waktu imobilisasi enzim, tidak berpengaruh signifikan terhadap morfologi permukaan TIMM-G.

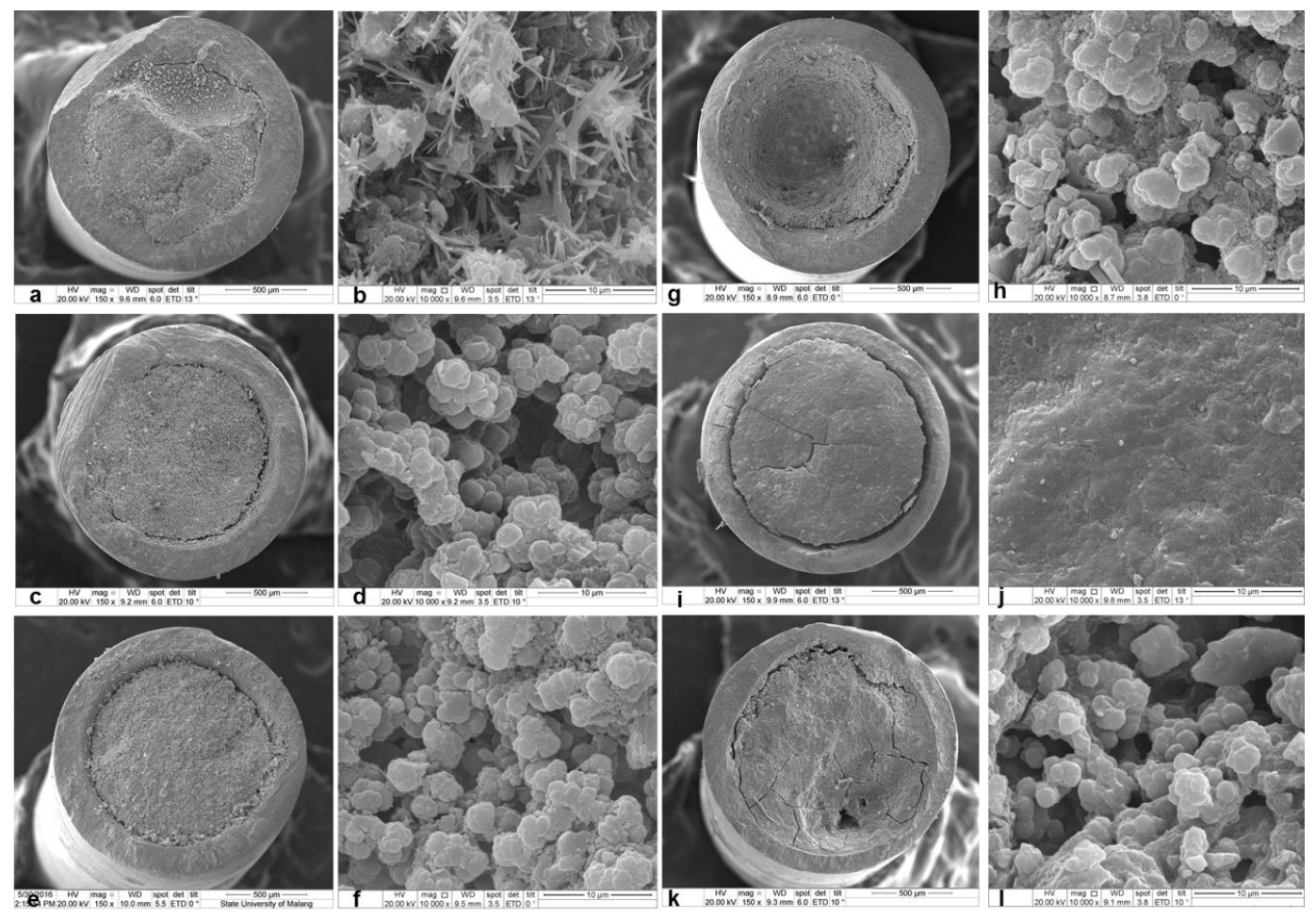

Gambar 3. Hasil SEM poli(GMA-co-EDMA) \%T 40 dan \%C 25, TIMM dan TIMM-G. TIMM 2 jam 150x (a), 10000x (b); TIMM 4 jam 150x (c), 10000x (d); TIMM 6 jam 150x (e), 10000x (f); TIMM-G 2 jam 150x (g), 10000x (h); TIMM-G 4 jam 150x (i), 10000x (j); TIMM-G 6 jam 150x (k), 10000x (l)

Pada permukaan TIMM-G juga mengalami cracking yang disebabkan oleh tingkat akomodasi stres yang muncul dari TIMM akibat pengaruh penambahan glutaraldehida. Stres dapat muncul dikarenakan adanya perubahan struktur morfologi dimana ketidakteraturan struktur morfologi dari TIMM berubah menjadi struktur morfologi yang lebih rapat, padat dan teratur. Selain itu, terjadi perubahan ikatan kimia pada monolit sehingga dimungkinkan globul-globul yang terbentuk pada
Hal tersebut ditunjukkan dengan morfologi permukaannya karena hampir keseluruhan permukaan terlihat sangat rigid. Adapun perbandingan profil SEM TIMM pada berbagai variasi waktu imobilisasi menunjukkan terbentuknya globul dan diantara globul tersebut terdapat flow-through pore. Apabila dilihat dari struktur morfologi antar masing-masing variasi waktu imobilisasi hampir tidak ada perbedaan yang cukup signifikan (Gambar 3 (a-f)). Namun, 
perbedaan antar variasi waktu imobilisasi dapat terlihat pada EDX yang menunjukkan persen komposisi atom $\mathrm{N}$, dimana pendekatan menggunakan atom $\mathrm{N}$ ini mewakili jumlah $\mathrm{N}$ pada enzim tripsin. Pada Tabel 3 menunjukkan bahwa TIMM dengan waktu imobilisasi 2 jam menghasilkan persen berat $\mathrm{N}$ lebih sedikit dibandingkan dengan waktu imobilisasi 4 dan 6 jam yaitu 6,$54 ; 12,40$; dan $10,79 \%$, secara berturutturut.

Hal ini dimungkinkan jumlah enzim tripsin yang bereaksi dengan gugus epoksida dari monolit belum mencapai optimum sehingga berpengaruh pada jumlah atom N. Imobilisasi optimum diketahui terdapat pada waktu imobilisasi 4 jam dengan jumlah persen komposisi atom $\mathrm{N}$ tertinggi. Waktu imobilisasi 6 jam mengalami penurunan jumlah $\mathrm{N}$ dimungkinkan enzim tripsin mengalami ketidakstabilan reaksi ketika berikatan dengan gugus epoksida dari monolit sehingga enzim terdegradasi/mengalami autolisis yaitu penurunan aktivitas katalitik di waktu imobilisasi yang lebih lama. Berdasarkan struktur morfologi pada hasil SEM (Gambar 3) dan persen komposisi atom N pada EDX kolom TIMM 4 jam mempunyai kemampuan digunakan sebagai mikroreaktor untuk proses digestion protein. Pada TIMM-G dilihat dari struktur morfologi permukaannya, tidak dapat dikatakan baik digunakan sebagai mikroreaktor untuk proses digestion sampel protein karena strukturnya yang sangat rigid dan teratur hampir tidak terbentuk globul dan flow-through. Oleh karena itu, TIMM dengan waktu imobilisasi 4 jam dipilih untuk diaplikasikan sebagai kolom mikroreaktor dalam proses digestion sampel protein.

\section{Kesimpulan}

Kolom monolit poly-(GMA-co-EDMA) dengan \%T 40 dan \%C 25 memiliki proporsi micropores, flow-through pore dan mesopores yang seimbang berdasarkan hasil ISEC yaitu 5,9 ; 65,8 dan $28,20 \%$. Kolom monolit poly-(GMA-coEDMA) terimobilisasi enzim tripsin (TIMM) dengan waktu imobilisasi 4 jam merupakan mikroreaktor yang paling baik karena mempunyai kestabilan mekanis dan permeabilitas yang baik, dengan jumlah persen komposisi unsur $\mathrm{N}$ tripsin paling tinggi yaitu $12,40 \%$.

\section{Ucapan terima kasih}

Penelitian ini sebagian didanai oleh Hibah Unggulan Universitas Tahun 2015-2016 dari Direktorat Jenderal Pendidikan Tinggi, Kementrian Pendidikan dan Kebudayaan, Indonesia.

\section{Daftar pustaka}

Al-Bokari, M., Cherrak, D., \& Guiochon, G., (2002). Determination of the porosities of monolithic columns by inverse sizeexclusion chromatography, J. Chromatogr. A, 975: 275-284.

Berthold, J., \& Salmen, L., (1997). Inverse Size Exclusion Chromatography (ISEC) for Determining the Relative Pore Size Distribution of Wood Pulps, STFI Stockh. Swed., 51: 361-368.

Bystrom, E. (2009) Porous polymeric Materials for Chromatography: Synthesis, Functionalization, and Characterization, Umea University, Sweden.

Chen, Y., Wu, M., Wang, K., Chen, B., Yao, S., Zou, H., \& Nie, L., (2011). Vinyl functionalized silica hybrid monolit-based trypsin microreactor for on line digestion and separation via thiol-ene "click" strategy, $J$. Chromatogr. A, 1218: 7982-7988.

Strigter, E.C.A., de Jong, G.J., \& van Bennekom, W.P. (2007). Development of an opentubular trypsin reactor for on-line digestion of proteins. Anal Bioanal Chem, 389: 1967-1977.

Kim, J., Kim, B.C., Lopez-Ferrer, D., Petritis, K., \& Smith, R.D., (2010). Nanobiocatalysis for protein digestion in proteomic analysis, proteomics, 10: 687-699.

Liang, Y., Tao, D., Ma, J., Sun, L., Liang, Z., Zhang, L., \& Zhang, Y., (2011). Hydrophilic monolith based immobilized enzyme reactors in capillary and on microchip for high-throughput proteomic analysis, $J$. Chromatogr. A, 1218: 2898-2905.

Monzo, A., Rejtar, T., \& Guttman, A., (2009). Optimization of poli(GMA-co-EDMA) Monolitic Support for Trypsin Nanoreactor Fabrication, J. Chromatogr. Sci., 47: 467472.

Safdar, M., Sprob, J., \& Janis, J., (2014). Microscale immobilized enzyme reactors in proteomics: Latest developments, 1324: 1 10. 
Shangguan, L., Zhang, L., Xiong, Z., Ren, J., Zhang, R., Gao, F., \& Zhang, W., (2015). Investigation of bi-enzymatic reactor based on hybrid monolit withnanoparticles embedded and its proteolytic characteristics, J. Chromatogr. A, 1388: 158-166.
Tasfiyati, A.N., Iftitah, E.D., Sakti, S.P., \& Sabarudin, A., (2016). Evaluation of glycidyl methacrylatebased monolit functionalized with weak anion exchange moiety inside $0.5 \mathrm{~mm}$ i.d. column for liquid chromatographic separation of DNA, Anal. Chem. Res, 7:9-16. 